\title{
LIVING ON A CONSTRUCTIVE PLATE BOUNDARY
}

by

Ingvar Birgir Fridleifsson

\begin{abstract}
Having lived most of his life about $15 \mathrm{~km}$ west of the boundary between the Eurasian plate and the North American plate as it passes through Iceland, the author describes from both personal experience and scientific insight the effects that inter-plate activity has on the lives of Icelanders. His timely article also outlines the current magma-tectonic episode occurring under the Krafla caldera in North Iceland.
\end{abstract}

\section{Volcanoes and Earthquakes}

Iceland lies astride the Mid-Atlantic Ridge, which is a constructive plate margin. People living in relative safety on a mid-plate continental crust are bound to wonder what life on an active plate margin is like. There are certainly some stark facts to be considered.

If it were not for the extraordinary volcanic activity at $64^{\circ}-66^{\circ} \mathrm{N}$, Iceland would not jut out of the sea at all. Most of the active volcanoes are confined to the uninhabited highland areas. On average, there has been about one volcanic eruption every five years over the last few centuries. About $1 \%$ of the surface of the country has been covered by new lava flows during the 1100 years of settlement; lava flows are known to have destroyed several farm houses in centuries past and to have partially covered the grazing land of others.

All the same, Icelanders would hardly have considered lava flows to be a potential danger were it not for a volcanic fissure which opened up a few hundred meters from the edge of a thriving fishing town on the island of Heimaey off the south coast of Iceland in January, 1973. The 5,300 inhabitants were evacuated in a matter of a few hours and there were no casualties, but about one-third of the houses were destroyed by lava and tephra during the five months the eruption lasted (Fig. 1).

The tephra fall, so characteristic of many of the country's prominent volcanoes, such as Hekla, has in fact caused much more damage through the centuries than has lava. The worst famine in the island's history was connected with the Laki eruption of 1783 when about $12 \mathrm{~km}^{3}$ of lava covered an area of $565 \mathrm{~km}^{2}$. Tephra and gases from the eruption destroyed the grasslands over large parts of the country. About $50 \%$ of the cattle and nearly $80 \%$ of sheep and horses in the country died of starvation and poisoning and over $20 \%$ of the population perished in the two years following the eruption.

While earthquakes are common in Iceland, most tend to be smaller than 6 on the Richter scale. Every century or so one can expect from four to eight earthquakes registering a magnitude of 6 or larger. The focal depth of the earthquakes is normally less than $10 \mathrm{~km}$.

Only about $10 \%$ of the people live in the zones that may be termed dangerous; most Icelanders live some $20 \mathrm{~km}$ or more away from the potential epicenters of large earthquakes, and so less than 100 people have been killed in earthquakes during the last eight centuries. About half of these perished during three earthquakes in the 13 th century. Most houses today are built of reinforced concrete with a view to withstanding possible earthquakes.

\section{Geothermal Energy}

These are the bleaker sides of volcanoes and earthquakes, but there are also benefits. First of all, due to the intense volcanism, the country is very mountainous. Set in an oceanic climate, mountains cause heavy precipitation. Thus Iceland's higher relief and abundance of water provides substantial hydroelectric resources.
Secondly, due to the intense magmatic activity at the plate boundary passing through the country, the regional heat flow is very high. The heat flow, as measured in $100 \mathrm{~m}$ deep drillholes outside known geothermal fields, varies from about 2 HFU furthest away from the active volcanic zones crossing the country to about $7 \mathrm{HFU}$ in some regions at the outer margins of the longest lived volcanic zone. Due to the high heat flow, hot springs are very abundant in the lowlands outside the active zones of rifting and volcanism. Inside these zones, there are at least two steam fields which are thought to draw heat both from the very high regional flow and from local accumulations of igneous intrusions cooling at a shallow depth in the crust.

Through the centuries, hot springs were used only for washing and bathing. It was not until after World War II that large-scale use of geothermal water was started, mainly in the form of space heating (houses and greenhouses). Geothermal steam is now also used for power production and industrial processing, such as drying of diatomite slurry or drying of seaweed for alginate production. The geothermal water used for space heating is mostly from low temperature areas (temperatures less than $105^{\circ} \mathrm{C}$ at $1 \mathrm{~km}$ depth in the ground); the content of dissolved solids is generally of the order of 200-400 ppm, and the water can be used directly.

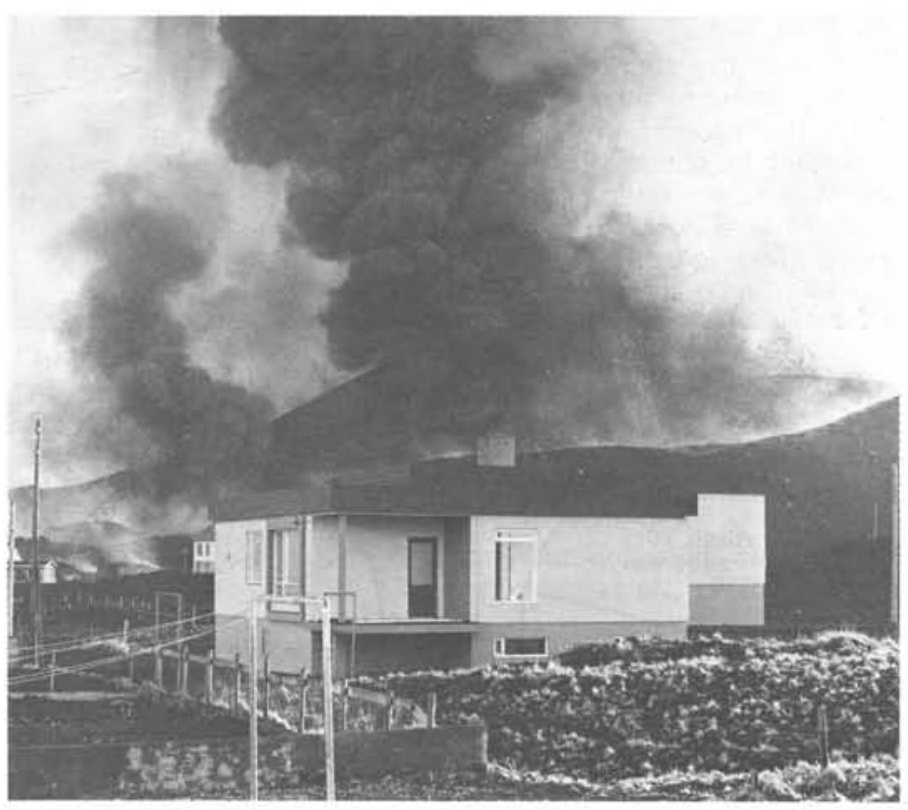

Figure 1

A volcanic fissure opened up about $300 \mathrm{~m}$ from the edge of the town on the island of Heimaey in 1973. This photograph was taken on the third day of the eruption. The house in the foreground was later engulfed by lava. At the end of the eruption, the thickness of lava was about $60 \mathrm{~m}$ at this particular location. 
One of the geothermal stations has recently started perating in a steam field where a $240^{\circ} \mathrm{C}$ brine $(2 / 3$ seawater $)$ $s$ used for district heating in a unique heat exchange process. ome of the geothermal steam is also used to generate lectricity for in-plant needs. On the island of Heimaey, owever, an even more remarkable achievement has been ealized: here heat is extracted for space heating from the till partly molten lava flow which engulfed a part of the own in 1973. At present, about $15 \%$ of the houses in the fast xpanding town are heated this way. It is estimated that leat could be extracted economically from the lava for the whole town for at least the next ten years.

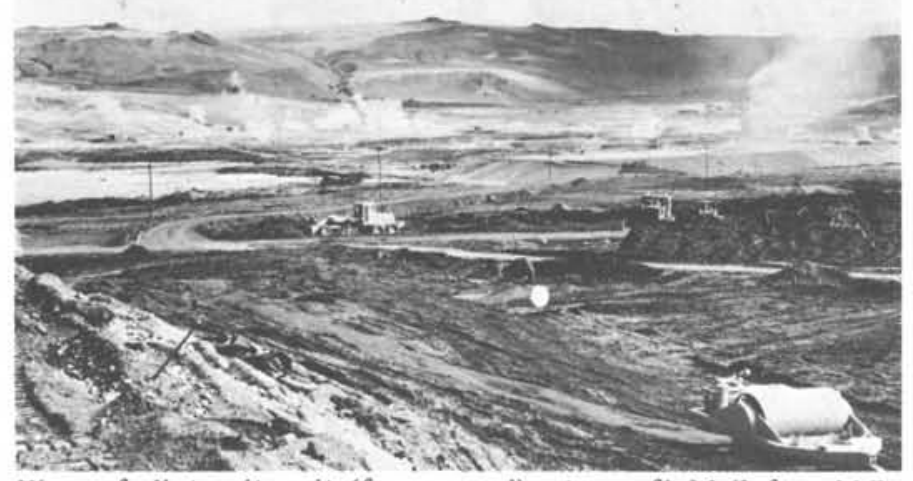

View of diatomite pit (foreground), steam field (left middle background) and diatomite plant (right middle background).

When the energy crisis came to a head in the early seventies, Iceland, like most countries, tried to increase the use of the country's natural energy sources, hydroelectric and geothermal energy, and to cut down on the use of fossil fuel which has to be imported into the country. This effort has been successful (see Fig. 2): the total net energy consumption increased by about $23 \%$ from 1972 to 1976 , yet the increase has been met entirely by hydroelectric power and geothermal energy.

Over this four-year period, while hydropower consumption increased by $40 \%$ and geothermal energy consumption by $43 \%$, oil consumption stayed constant in spite of the steadily increasing numbers of cars and fishing vessels. Between $60 \%$ and $70 \%$ of the buildings in Iceland are now centrally heated by thermal water. It has been estimated that the nation is saving close to 2 metric tons of fossil fuel per inhabitant per year by using geothermal energy.

1972

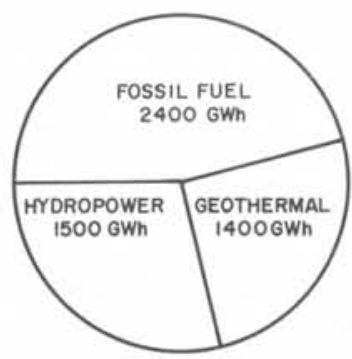

Figure 2

A comparison of the net energy consumption of Iceland in 1972 and 1976. The data is calculated from the records of the National Energy Authority, Reykjavik, Iceland.

\section{The Present: A Rifting Episode on the Plate Boundary}

The more we harness the primary forces of the plate boundary, the more we become aware of and depend upon its behaviour. The clearest and most current example is the $80-\mathrm{km}$ long Krafla fault swarm in northern Iceland. In 1967, a large plant using geothermal steam for drying diatomite mud pumped from a nearby lake started operating in the Namafjall steam field in the southern part of the Krafla fault swarm, about $5 \mathrm{~km}$ south of the rim of the Krafla caldera. A $3 \mathrm{MW}$ power station was also erected in the field. In 1975, construction started on a $60 \mathrm{MW}$ power station in a steam field inside the Krafla caldera. The fault swarm passing through the caldera had last been active in 1724-1729, and no abnormal seismic activity had been encountered in the last few decades. Late in the summer of 1975, seismic activity increased in the fault swarm, and by December, a small volcanic eruption occurred inside the Krafla caldera. An intense earthquake swarm and ground deformation accompanied this, indicating movement on an $80-\mathrm{km}$ segment of the plate boundary.

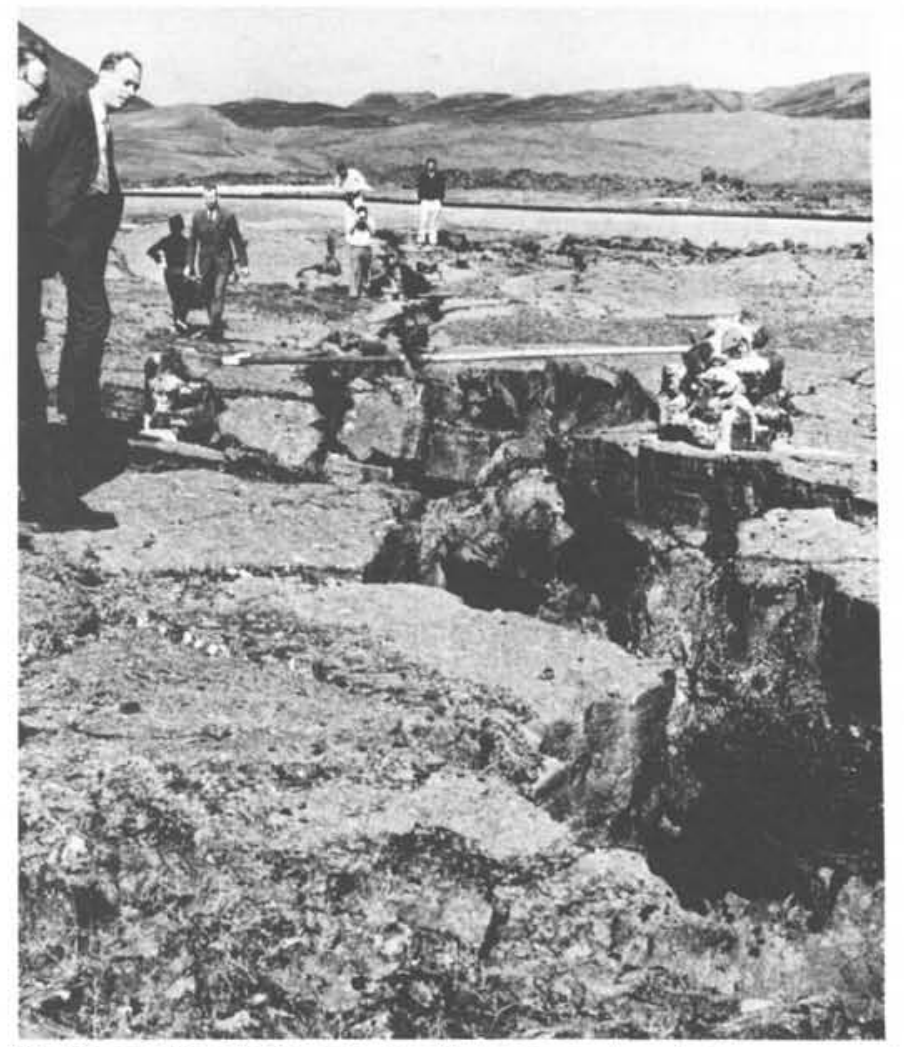

Strain guage which has itself been ruptured by movement along a fault in the Krafla swarm.

Since then the plate boundary has been breathing relatively regularly (Bjornsson et al., 1978). There appears to be a constant inflow of about $5 \mathrm{~m}^{3} / \mathrm{s}$ of magma into a magma chamber inside the Krafla caldera. The top of the magma chamber is about $3 \mathrm{~km}$ in depth. The inflow of magma causes continuous inflation of the caldera at a rate of $7-10 \mathrm{~mm}$ per day at the middle. At a certain level of inflation, generally after a few months, the magma seems to break a threshold. A period of rapid deflation of the floor of the caldera then begins, accompanied by a sudden expansion of a segment of the fault swarm (in the order of meters), a less pronounced contraction of the ground outside the fault swarms, earthquake swarms, and vertical ground movements of up to two meters. The deflation appears to be caused by a rapid lateral flow of magma from the chamber inside the caldera along the fault swarm north and south of the caldera. The flow of the magma can be traced with the aid of seismometers. 
In the nine deflation events that have occurred since 1975, lava has erupted three times, but more often the lava is emplaced at shallow depths along the fault swarm, giving rise to new fumarole fields where it heats up the ground-water. The striking displacement on individual faults has caused heavy damage to houses, roads, power and telephone lines, drillholes, and the storage ponds at the diatomite factory.

On September 6, 1977 deflation started at 15.47h after a period of inflation which lasted over four months. Seismographs showed volcanic tremors, and a volcanic eruption started at about $19.00 \mathrm{~h}$ near the northern rim of the caldera; the volume of lava erupted was about $2 \times 10^{6} \mathrm{~m}^{3}$. From seismographic readings, it also became apparent that magma was transported southwards from the caldera along the fault swarm. At about $23.45 \mathrm{~h}, 3$ tons of basaltic scoria erupted along the $1138 \mathrm{~m}$ deep drillhole (Fig. 3) in the Namafjall steam field $12 \mathrm{~km}$ south of the active crater on the northern caldera rim. The eruption lasted 20 minutes (Larsen et al., 1978).

For the first time in history, the diameter of a volcanic vent was measured exactly. There is a 7 -inch casing down to $380 \mathrm{~m}$, a 5 -inch casing from $350-625 \mathrm{~m}$; below that level there is no casing and the diameter is $61 / 4$ inches. The pipe on the well head (through which the lava erupted) was later repaired and it has been used since for steam production. Steam is emitted also in large quantities through the faults which formed in the ground of the steam field; this has made working conditions in the field very difficult if not downright hazardous.

Two deflation events have occurred since the drillhole erupted. On both occasions the magma was apparently transported northward along the fault swarm. By the end of October this year, inflation reached a new peak, and deflation could be expected any day. A continuous surveillance is now kept on the plate boundary. The power house itself inside the Krafla caldera is used as a tilt meter for recording the inflation, and there are three other continuously recording tilt-meters in Krafla and near the Namafjall steam field. There is continuous recording of hydrogen from a fumarole in the fault swarm. The width of selected faults is recorded daily and there is a 24-hour watch on the seismographs.

This state of affairs will remain on the plate boundary in northern Iceland as long as magma is being fed up into the magma chamber under the Krafla caldera. The last magmatectonic episode on this particular fault swarm lasted for five years (1724-1729). Present activity resembles the historic records of that episode quite closely. The plate boundary in northern Iceland consists of several such fault swarms and, judging by historic records, it seems to move in spasms on one of the swarms about once every century. In order to live in peace with the plate boundary, Icelanders have learned to know its nature and the characteristics of its behaviour.

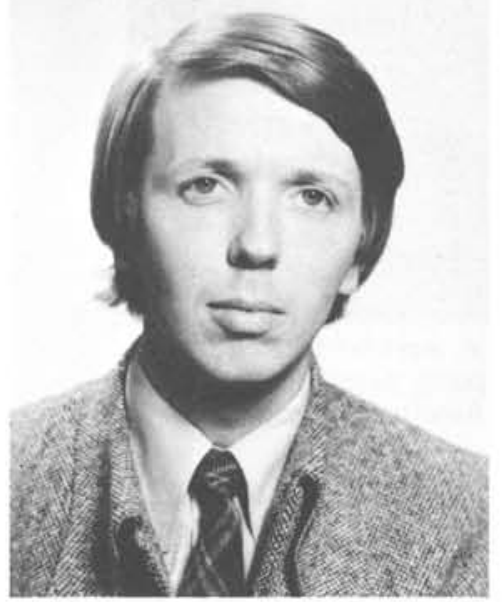

ABOUT THE AUTHOR: Ingvar Birgir Fridleifsson received his B.Sc. from St. Andrews's University, Scotland, and his D. Phil. in geology from Oxford University, England, in 1973. Since then, he has been working in the Geothermal Division of the National Energy Authority in Reykjavik, Iceland on geothermal exploration, geological mapping, petrological studies, and structural modelling of geothermal fields.

\section{References}

Bjornsson, A., Johnsen, G., Sigurddson, S., Thorbergsson, G., and Tryggvason E., 1978, Rifting of the plate boundary in North Iceland: Report of the National Energy Authority OS JHD 7821 and the Nordic Volcanological Institute 7807, Reykjavik.

Larsen, G., Gronvold, K., and Thorarinsson, S., 1978, Volcanic eruption through a geothermal borehole at Namafjall, Iceland: Report of the Nordic Volcanological Institute 7812 and the Science Institute RH 7810, Reykjavik.

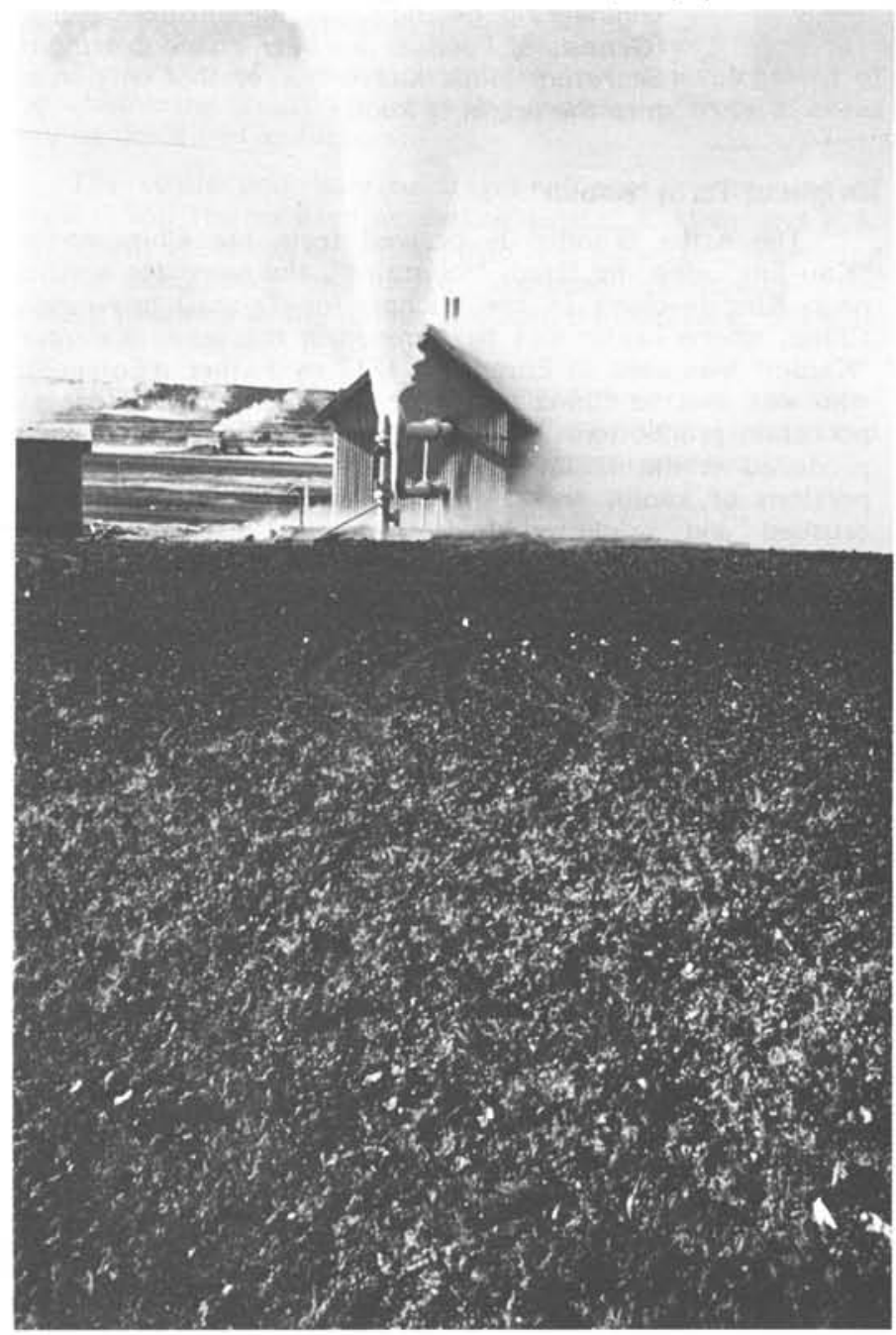

Figure 3

The borehole in the Namafjall steam field on the morning after the eruption in September 1977. The steam jet is emitted through the rupture in the pipe created by the volcanic eruption. In the foreground: car tracks on the freshly fallen tephra. The median grain size of the very frothy fragments was about $2 \mathrm{~cm}$, but unbroken clasts were commonly up to $15 \times 10 \times 4 \mathrm{~cm}$ (Larsen et al., 1978). (Photo courtesy $S$. Thorarinsson) 